\begin{tabular}{|c|c|c|c|}
\hline & & Volumet & mination. \\
\hline & $\begin{array}{l}\text { Gravity } \\
\text { determination, } \\
\text { Per cent. }\end{array}$ & $\begin{array}{l}\text { By } \\
\text { theoretical } \\
\text { factor. }\end{array}$ & $\begin{array}{l}\text { By factor } \\
\text { of Dudley } \\
\text { and Pease. }\end{array}$ \\
\hline Steel & No. r......... 0.040 & 0.040 & 0.045 \\
\hline “ & $" \quad \ldots \ldots \ldots \ldots, \ldots$ & 0.040 & 0.045 \\
\hline “" & $\ldots \ldots \ldots \ldots, \ldots$ & 0.039 & 0.044 \\
\hline Stee & No. $2 \ldots \ldots \ldots, 0.053$ & 0.050 & 0.056 \\
\hline “ & $" \quad \ldots \ldots \ldots \ldots, \ldots$ & 0.052 & 0.058 \\
\hline Steel & No. $3 \ldots \ldots \ldots, 0.032$ & 0.029 & 0.032 \\
\hline "6 & $" \quad \ldots \ldots \ldots \ldots, \ldots$ & 0.034 & 0.038 \\
\hline$"$ " & $\ldots \ldots \ldots \ldots$ & 0.032 & 0.036 \\
\hline
\end{tabular}

It is evident that the theoretical factor gives results which agree closely with the gravimetric determinations while the results calculated by the empirical factor of Dudley and Pease are decidedly too high. The evidence that the precipitation of the phosphorus is practically complete is quite satisfactory. It will be remembered that steel No. 2 contains arsenic. Our results seem to indicate that the arsenic is not precipitated to an appreciable extent with the phosphorus.

If the theoretical factor for the ratio between the iron and phosphorous equivalents of a potassium permanganate solution shall be confirmed by other observers, as we feel confident that it will be, the volumetric determination will be placed on so firm a basis that, at least in the absence of arsenic, the results obtained by it must be considered as more reliable than those obtained by any gravimetric method now in use. This cannot be true so long as the determination depends on an empirical factor, for any empirical factor is likely to vary with the amounts of phosphorus present and would not be applicable to steels containing widely different amounts of phosphorus.

TERRE HAUTE, June 15, I894.

\title{
THE ANALYSIS OF MALT.
}

\section{By ToM Crossman. \\ Received June $\mathbf{8 8 ,} \mathbf{1 8 9 4 .}$}

I $\mathrm{N}$ the JourNaL for May, $\mathrm{I} 894$, there is an article on the analysis 1 of malt by Dr. Miller. As a few of Dr. Miller's statements are totally opposed by those who have given the chemistry of malt their life study, I feel justified in bringing before your readers the methods of analysis which are in use for the valuation 
of English malts in all our large breweries. The methods being based on the splendid researches of O'Sullivan, Heron, Brown, Morris, and others. I am aware that for the English infusion mashing we require better malt than when practicing the Cerman decoction system. No doubt the methods given by I)r. Miller would give satisfaction to those brewers working on the German principle; but I make bold to assert, that a malt tested by the methods given in the article referred to, would not give information to the brewer which would be of any great practical guidance to him.

Dr. Miller asks, "From the standpoint of the brewer, the largest consumer of malt, what are the most important points to be ascertained by the analysis of a malt?" He then gives them as follows:

I. Moisture.

2. Extract.

3. Diastatic power.

4. Acidity.

I may add that the above factors do not tell the brewer much; but when taken in conjunction with the following, the results give him information of the greatest possible value.

5. Ready-formed sugars, soluble in cold water.

6. The percentage of uncoagulable albuminoids, soluble in cold water.

7. The quantity of free maltose, malto-dextrins, and free dextrin, when the malt is mashed under standard conditions.

8. The amount of unmodified starch or steeliness.

With reference to No. 1 , nothing need be said as far as the method is concerned; but no practical brewer would ever dream of using malt containing five per cent. of moisture. Malt having three per cent. is generally looked upon with suspicion if required for a stock ale. One per cent. is normal to a good well-cured, and properly stored article.

The determination of moisture does not in all cases give us the information whether the malt has been properly dried or not originally, since it might have gained the water during careless storage. No brewer of my acquaintance thinks of judging the price of malt by the amount of water it contains, since he 
knows fully well that the increase in moisture means increased deterioration.

2. The extract is usually determined by English chemists by what is known as Heron's method. ${ }^{\prime}$ It consists of mashing fifty grams of ground malt with $400 \mathrm{cc}$. of water at $68^{\circ} \mathrm{C}$., and keeping the temperature of the mash at $65^{\circ}-66^{\circ} \mathrm{C}$. for one hour. Afterwards the mash is cooled to $15.5^{\circ} \mathrm{C}$. and made up to $515 \mathrm{cc}$. ( $500 \mathrm{cc}$. water, $5 \mathrm{cc}$. for space occupied by grains). The gravity is taken and the extract calculated therefrom. The wort is reserved for the further analysis, 7 .

Heron's method is one which has given great satisfaction, since it is possible to analyse the starch products and compare them with other malts, giving information which is very much appreciated by practical brewers. The method is, by far, preferable to that following the conversion with iodine.

As opposed to Dr. Miller's statement I find that the majority of ale brewers are more guided, when purchasing malt, by the quality of the extract, as determined by the tests I am enumerating, than by the quantity.

3. The diastatic capacity is best determined by Lintner's method, which gives us the amount of curing the malt has been subjected to. It must not be forgotten, however, that two malts, each having the same diastatic power, will not behave the same, even if mashed under identical circumstances, unless the starch in each is in the same state of friability or freeness. Since, if the one malt is hard and vitreous and the other is free, the diastase will have more "work" to perform in the former than in the latter; therefore, the relative amounts of free maltose and malto-dextrin will be quite different. This is a point overlooked by several, they thinking if malts contain a given quantity of diastase, all the starch conversions will be the same providing the temperatures are similar. This is not so. The estimation of the diastatic power is not of much use unless we know the condition of the starch as determined by 7 and 8 .

4. The acidity needs no comment.

5. The percentage of ready-formed sugars convey to the brewer more information as to the quality of the malt than is generally

1 The Polariscope and Its Application to Brewing, ( $J$. Soc. Chem. Ind., 7, 259-276). 
supposed. If the amount is low it is evident that the barley has been insuffeiently getminated. If the guantity is high $i$ i. orel serenteen per (ent, calculated on the malt) brewers andet that the beer proluced from weth a malt will not be somme: it also goes to prove that the malt has been forced or tor quickiy grown on the floors at high temperatures.

6. The anonnt of uncoayulable albuminoids and the anount of reach-formed sugass seem to bear a relation to each other. Moritz has publisher some rery interesting experinents which go te prove that under conditions specially faroring the attack and transformation of starch into sugars, there is a similar specially active attack upon the original albuminoids and an abundant transformation of them into soluble forms. He also publishes at number of analyses of malts and in cach case he gives the factor obtained by dividing the soluble albuninoids into ready-formed sugars. It is a nost noticeable fact that this lacum is either $6 . ;$. or a figure closely approximating it. There is sufficient proot here to convict the most skeptical. that it is absolutely imposisble for a chemist to estimate the value of malt without first determining 5 and 6 .

7 . 13y the estimation of free maltose and malto-dextrins, we get the knowledge how the starch is converted into the different sugars. It supplies to the brewer more information than it is at first possible, by non-brewers, to conceive; since it informs him how the starch behaves at fixed temperatures and conditions, he can then, to suit the class of beer lie is desiring to produce, arrange his mashing heat with a certain amount of reliability.

I)r. Miller sass, "It has been clamed by some that the percentage of sugars formed, and the andount of proteids dissolved, is of importance in judging the character of malt.' I clain that the amount of sugars formed is very inportant in juclging the character of malt, provided all malts ate mashed uncler standard conditions, as is done when using Heron's method. I an aware that the increase or decrease of the percentage of the various transformation products is entirely dependent upon the namer in which malt is handled in the mash-tub, combincd ith the condition of the starch and the amount of diastasc. 'Therefore, if the

1 Technical Brewing: a keport on bhe chief features, in the year lay. 
brewer gets information as to the amount of the various sugars a malt yields when mashed under known conditions, surely he has a sound foundation upon which he can base his ideas in guiding him in the manner which the malt should be handled in the mash tub. The amount of free maltose and malto-dextrin in a wort, determine, to a very large extent, the condition, flavor and attenuation of the resultant beer. I cannot sufficientiy emphasize the great importance of these determinations to the practical man.

8. The amount of unmodified starch or steeliness.

This a test of some significance, but not generally practiced. Its advantages are that it gives us the amount of unnodified or vitreous starch.' It will be as well if I state the objects of malting, so as to better illustrate the importance and advantages of this test. The principal objects of malting are: The dissolution of the cellulose forming the cells in which the starch grantiles are enclosed, and the consequent liberation of the starch; the breaking down of the nitrogen constituents of the corn; the production of diastase for the future service in the mash-tub. Now, when the original barley is bad, or the malting has not been carried out on proper lines, the cellulose surrounding the starch granules is not dissolved, the starch is "locked up," so to speak. and in a very refractory condition making it well nigh impossible for the diastase to convert it at ordinary temperatures. A large amount of starch is then left in the grains, which may possibly get "semi-dissolved" and partly washed out by the subsequent higher sparging heats, and not being converted makes the production of gray or hazy beer very easy. If it were only a matter of dealing with steely malt we could surmount the difficulty by the decoction system of mashing; but it is understood that when the dissolution of the cellulose forming the cells is not satisfactory we have evidence of the glutens being only partly modified, and the resultant beers will not be as brilliant as those produced by a fully modified malt. Thus, a malt gives the best results in practice when the amount of unmodified starch, as estimated below, is small, providing other conditions are favorable. The following is the method I have used the last two years and have found exceedingly useful: 
Fifty grams of malt are mashed, as in $\rightarrow$; the mash is then boiled very vigorously for one hour and afterwards cooled to $150^{\circ} \mathrm{F}$. Fifty cc. of a cold water extract, previously prepared, as described below, are now added; the mash is kept at $150^{\circ} \mathrm{F}$. for one hour longer. It is now cooled down to $60^{\circ} \mathrm{F}$. and made up, as in 2, to $5 \mathrm{r} 5 \mathrm{cc}$. The gravity is taken, allowance being made for the gravity added, $i$. e., ffty cc. cold water extract. The difference in solid matter between boiled mash and mash, (2), will give the amount of unmodified starch. Fxample:

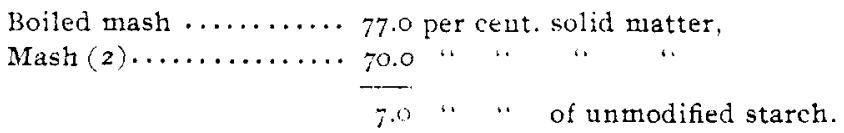

The following is, in my opinion, the manner in which the results of malt analyses should be stated.

COMPOSITION OF WORT MASHEB LNHER STANDARD CONDITIONS.

Free maltose, fermentable $\ldots \ldots \ldots \ldots \ldots \ldots \ldots \ldots \ldots \ldots, 33.30$

Ready-formed sugars, fermentable.................. 14.08

Malto-dextrins, unfermentable $\left\{\begin{array}{c}\text { maltose, } 3.0 \\ \text { dextrin, } 1.9\end{array}\right\} \ldots \ldots \ldots . . .64$

Free dextrin, unfermentable...................... 53.40

Albuminoids $\ldots \ldots \ldots \ldots, \ldots \ldots \ldots, \ldots, \ldots, \ldots, \ldots, \quad 2.21$

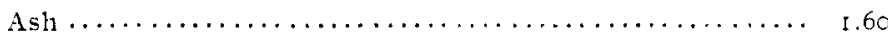

Acid as lactic acid $\ldots \ldots \ldots \ldots \ldots \ldots \ldots \ldots \ldots \ldots \ldots, 0.5 \mathrm{I}$

Total dry extract $\ldots \ldots \ldots \ldots \ldots \ldots \ldots \ldots \ldots, 70,00$

Unmorlified $\operatorname{starch} \ldots \ldots \ldots \ldots \ldots \ldots \ldots \ldots \ldots \ldots \ldots, 7,00$

Moisture ................................... 1.90

Grains $\ldots \ldots \ldots \ldots \ldots \ldots \ldots \ldots \ldots \ldots \ldots \ldots \ldots \ldots, 21,10$

Diastatic capacity ............ 30 .

100.00

Color of wort .............. pale.

Flavor................... good.

When the amount of unmodified starch exceeds much over seven per cent. it is sufficient to regard the malt with suspicion. A remarkable thing and an undisputed fact is, that beer made from a good foreign malt is more sound and brilliant than when made from good English malt. Yet, on comparing the analysis of each, we find that the unmodified matter, ready-formed sugars and soluble albuminoids, are smaller in amount in the foreign 
than in the English malt. This speaks volumes for the value of malt analysis when conducted as described above.

Note.-Preparation of cold water malt extract. Fifty grams of ground malt are added to $500 \mathrm{cc}$. cold distilled water, and allowed to stand four hours with frequent stirriug, It is then filtered absolutely brilliant, and used as directed.

THE LABORATORY, AEBION BREWERY,

OLDHAM, ENGLAND.

\section{ON THE REACTION BETWEEN MOLYBDIC ACID AND POTASSIUM CHROMATE AND BICHROMATE.}

BY ROBERT H. BRADBURY.

Received June $2 \mathrm{r}, \mathbf{1 8 9 4}$.

MLYBDENUM, as its position in the periodic system of VI the elements would indicate, offers many analogies with sulphur and more particularly with chromium. Thus, the most important acid of each is $\mathrm{H}_{2} \mathrm{RO}_{4}$, and the most stable acid-forming oxide $\mathrm{RO}_{3}$. Again, sulphur and chromium have for some time been known to form a higher unstable oxide $\mathrm{R}_{2} \mathrm{O}_{1}$, and more recently a hydrated $\mathrm{Mo}_{2} \mathrm{O}_{7}$ has been prepared and investigated.

Potassium bichromate, $\mathrm{K}_{2} \mathrm{Cr}_{2} \mathrm{O}_{7}$, is more fully written $\mathrm{K}_{2} \mathrm{CrO}_{4} \mathrm{CrO}_{3}$, that is, it consists of a molecule of the neutral chromate combined with a molecule of chromic anhydride, and still higher anhydrochromates, $e$. $g$., potassium trichromate, $\mathrm{K}_{2} \mathrm{Cr}_{3} \mathrm{O}_{11}$ or $\mathrm{K}_{2} \mathrm{CrO}_{4} \mathrm{CrO}_{3}$, have been shown to exist. The marked likeness between molybdenum and chromium led to the supposition that it might perhaps be possible to replace the chromium in potassium bichromate by molybdenum-that is, to obtain a compound $\mathrm{K}_{2} \mathrm{CrO}_{4} \cdot \mathrm{MoO}_{3}$. Since the bichromate results by the direct addition of chromic anhydride to the neutral chromate, it was supposed that the hypothetical chromo-molybdate might result by simple addition of molybdic anhydride to potassium chromate, thus

$$
\mathrm{K}_{2} \mathrm{CrO}_{4}+\mathrm{MoO}_{3}=\mathrm{K}_{2} \mathrm{CrO}_{4} \cdot \mathrm{MoO}_{3} \text {. }
$$

At the suggestion of Dr. Smith I have investigated this subject, and while the result is not what was expected, it is of interest as adding another to the long list of facts which show that the rôle played by a substance in a reaction depends not only on the special qualities of the substance, but also to an equal degree on the amount in which it is present. The reaction which ensues when molybdic anhydride is brought together 